\title{
Takeover Defense Tactics and Legal Scholarship: Market Forces Versus the Policymaker's Dilemma
}

\author{
Jonathan R. Macey†
}

\section{INTRODUCTION}

A response to the interesting comment by Professors Gordon and Kornhauser ${ }^{1}$ seems appropriate, not so much because the observations it contains about $A$ Theoretical Analysis of Corporate Greenmail ${ }^{2}$ are controversial, as because it presents a valuable opportunity to make more general observations about the nature of the current debate in corporate law concerning the proper role of target management confronted with a hostile takeover bid. ${ }^{3}$ Comparing the Gordon and Kornhauser comment with the Macey and McChesney article illustrates that the overarching difference between the two sides of this debate is not simply that they come up with different answers to the same questions. Rather, the difference stems from our vastly different scholarly agendas. Our article and their comment represent opposing genres of legal scholarship, which accounts for Gordon and Kornhauser's dissatisfaction with A Theoretical Model of Corporate Greenmail.

$\dagger$ Associate Professor Emory University School of Law. A.B., Harvard University; J.D., Yale University. Visiting Associate Professor, University of Virginia. I thank Saul Levmore for helpful comments on an earlier draft. Unfortunately, conflicting travel schedules and other commitments prevented Professor McChesney and me from producing a joint reply to the Comment by Professors Gordon and Kornhauser. The Yale Law Journal graciously permitted us to file separate replies. Having read McChesney's paper, I now concur with his observations and incorporate them by reference into my own reply.

1. Gordon \& Kornhauser, Takeover Defense Tactics: A Comment on Two Models, 96 YALE L.J. 295 (1986).

2. Macey \& McChesney, A Theoretical Analysis of Corporate Greenmail, 95 YALE L.J. 13 (1985)

3. On one view, management should be prohibited from taking action that would either increase the acquisition costs of the initial bidder or lower the probability of the initial bidder's success in the attempted acquisition. See, e.g., Easterbrook \& Fischel, The Proper Role of a Target's Management in Responding to a Tender Offer, 94 HARV. L. REv. 1161 (1981); Easterbrook \& Fischel, Auctions and Sunk Costs in Tender Offers, 35 SraN. L. REv. 1 (1982); Schwartz, Search Theory and the Tender Offer Auction, 2 J.L. EcoN. \& ORG. (forthcoming 1986). Under the competing view, incumbent management should be allowed to resist defensive tactics, but only to the extent necessary to facilitate the creation of an auction market for the firm's shares. See, e.g., Bebchuk, The Case for Facilitating Competing Tender Offers, 95 HaRv. L. REv. 1028 (1982); Gilson, A Structural Approach to Corporations: The Case Against Defensive Tactics in Tender Offers, 33 STAN. L. REv. 819 (1981). 
This reply will show that the difference in our scholarly agendas is attributable to a fundamental disagreement concerning the necessity for regulation to replace the contractual nexus that forms the underpinnings of the modern corporation. The difference between our article and their comment is profound indeed-perhaps even more profound than Gordon and Kornhauser recognize-and ought not be mistaken for a mere dispute about the legal propriety of a particular defensive tactic in tender offer contests.

By emphasizing the difference between our approaches, I am not suggesting that the form of discourse we employ is somehow better than Gordon and Kornhauser's, only that it is different. The difference must be stressed, however, so that the two sides do not continue to talk past each other.

\section{Differing Approaches to Greenmail-OUrs and Theirs}

Gordon and Kornhauser's approach to corporate law identifies a "problem" (the payment of greenmail), and then seeks to provide a "solution" (banning the practice). By contrast, our approach does not assume that practices such as greenmail are problems. Instead, it more modestly assumes that such practices are phenomena, albeit controversial ones, that need to be better understood. The issue of whether, much less how, greenmail ought to be regulated was not really a consideration in our article. Indeed, the only policy conclusion we reached in our article was that managerial motivation - the standard often used to test the legality of greenmail payments-is a poor guide to policy.

Gordon and Kornhauser chastise us for not answering certain questions about the propriety of paying greenmail." While we find their questions interesting, we approach the greenmail issue from an entirely different perspective and ask an entirely different set of questions. It is inappropriate to judge our article using their approach as the standard.

Our article attempted to construct a theoretical model to explain the emergence of corporate greenmail. Their comment, however, takes our article to be another "here's a problem-here's our solution" law review paper of the sort judges and lawyers find useful. This false assumption has led Gordon and Kornhauser to saddle us erroneously with a particular solution to the greenmail problem.

4. The primary question that we have not answered is why there should be a legal rule permitting the payment of greenmail. See Gordon \& Kornhauser, supra note 1, at 312 . In addition, Gordon and Kornhauser suggest that we do not clarify our presumption that managers of firms who pay greenmail are conscientious rather than self-interested. Id. at 312-13. With respect to the second question, our model of greenmail does not depend on conscientious managers. See infra text accompanying notes 26-28. 
Gordon and Kornhauser approach the issue from the perspective of a policymaker attempting to determine whether there should be a general rule (presumably a statute) absolving managers who pay greenmail from legal liability. The answer that they ascribe to us is "yes." Gordon and Kornhauser's basic criticism of our article is that we did not prove our case for granting pardons to managers who pay greenmail. But we did not attempt to present a case for managerial pardons in our article; in fact, we oppose the rule that they claim we advocate.

The only rule we favor is the one that allows shareholders, and thus markets, to determine when managers should have discretion to authorize the payment of greenmail. ${ }^{5}$ This position stems from the fact that some greenmail payments make shareholders better off and others make shareholders worse off. Any blanket rule either permitting or banning greenmail payments thus would harm some shareholders.

\section{A. Our Approach: Studied Agnosticism}

Our goal in writing our article was to "present[] a more complete theory of greenmail than has yet been attempted and examine[] the explanation of greenmail offered by those who would regulate the practice."8 In developing our theory, we first wanted to summarize the current wisdom regarding the propriety of such payments. ${ }^{7}$ Next, we tried to place the greenmail phenomenon within the context of current legal and economic theories concerning the desirability of defensive tactics. Finally, we strove to articulate a coherent theory of greenmail that reconciled the impressive quantity of empirical data that was available to us.

It is important to recognize what we did not do. First, we did not start with any assumptions about whether greenmail payments in the aggregate are good or bad for shareholders. Next-and this is the hallmark of the mode of discourse that we employed-we approached greenmail as an economic phenomenon in need of explanation rather than as a social problem in need of correction. We attempted to explain what initially interested us in the greenmail phenomenon, namely, how shareholders might on average benefit from the payment of greenmail.

Because our theory led us to conclude that there are many different reasons why firms pay greenmail, we were not able to formulate a legal

5. Macey \& McChesney, supra note 2, at 60 ("When evaluating greenmail payments, courts should focus first on whether the managers who paid greenmail violated any express or implied agreement not to make such payments.").

6. Id. at 15 .

7. Id. at 14. For a summary that appeared after our article, see Note, Greenmail, Targeted Stock Repurchases and the Management-Entrenchment Hypothesis, 98 HARV. L. REv. 1045 (1985); $c f$. Gordon \& Kornhauser, supra note 1, at 311-12 (describing "standard account" of greenmail phenomenon). 
test for evaluating greenmail payments. In fact, we found that sometimes target managers who pay greenmail for the "right" reasons (such as creating an auction market) may end up losing shareholders' money, while target managers who pay greenmail for the "wrong" reasons (such as trying to hold onto their jobs) may end up creating wealth for shareholders. ${ }^{8}$ While we did not formulate a legal test to be used in evaluating individual greenmail payments, our model suggested what questions such a test would address ${ }^{9}$ and allowed us to evaluate the test currently used by courts to determine the legality of greenmail payments. ${ }^{10}$

At the time we wrote our article, several empirical studies of the greenmail process showed that shareholders whose firms paid greenmail enjoyed statistically significant gains of approximately two percent. ${ }^{11}$ In other words, the studies showed that greenmail led in the aggregate to gains for shareholders. The empirical evidence also showed that greenmail payments sometimes benefitted but sometimes harmed the shareholders of paying firms. ${ }^{12}$ Yet, while financial economists had amassed an impressive array of empirical studies about greenmail, they had made only limited attempts to develop a theoretical framework to explain the data. We attempted to provide this missing theoretical framework. The only theory that existed before we wrote our article posited that agency costs explained all greenmail payments. ${ }^{13}$ In our article we observed that this theory explained but a fraction of observed greenmail payments. ${ }^{14}$ To explain the rest, we articulated a theory of how greenmail payments could enhance shareholder welfare. ${ }^{15}$ Our theory did not purport to explain all greenmail payments. Rather, it explained why the payment of greenmail is a net positive event for the shareholders of many firms. The burden is hence on those who favor regulating greenmail to develop a means of de-

8. Macey \& McChesney, supra note 2, at 42-43, 57-59.

9. Initially such a test would address how any proposed legal rule could improve upon the intrafirm contracts that firms themselves could adopt. Since any hard and fast rule restricting greenmail would harm shareholders, the best regulation would be a default rule allowing shareholders to "opt out" of the statutory rule and enact the rule they prefer. See id. at 58 \& n.163. Most important, any legal test should draw upon the experiences of firms that have been involved in the greenmail process.

10. Id. at 50-61.

11. These studies started from the point at which the greenmailer initially purchased target firm's stock, ended with the payment of greenmail itself, and controlled for events that might have affected share prices. Holderness \& Sheehan, Raiders or Saviors? The Evidence on Six Controversial Investors, 14 J. FIN. EcoN. 555, 571-72 (1985); Mikkelson \& Ruback, An Empirical Analysis of the Interfirm Equity Investment Process, 14 J. FIN. Econ. 523, 540 (1985) (Table 7); Poulson, Market Reaction to Corporate Raiders As Individuals (1984) (unpublished manuscript written under Office of Chief Economist of Securities Exchange Commission).

12. Macey \& McChesney, supra note 2, at 43-48 (summarizing empirical analyses).

13. Id. at 38-40. The agency cost explanation of greenmail is also known as the "managerial entrenchment hypothesis." Dann \& DeAngelo, Standstill Agreements, Privately Negotiated Stock Repurchases, and the Market for Corporate Control, 11 J. FIN. EcoN. 275 (1983).

14. Macey \& McChesncy, supra note 2, at 41-43.

15. Id. at 47 . 
termining ex ante which greenmail payments are likely to increase firm value and which are not.

\section{B. Their Approach: Regulatory Presumption}

Gordon and Kornhauser believe that research and writing about greenmail should focus on the question "how should policymakers distinguish tactics that will increase shareholder wealth and those that will not?"16 Their undertaking suggests that greenmail can be explained, as well as evaluated from a policy perspective. But the claim that there is a "policymaker's dilemma"17 regarding greenmail begs the underlying question whether greenmail should be regulated in the first place. Given the available empirical evidence, the need to ask this question becomes a matter of some significance. Gordon and Kornhauser assume that every innovation in corporate governance presents a "problem" to be regulated. They thus place far more confidence in the outcomes generated by the regulatory process than McChesney and $\mathrm{I}^{18}$ For us regulation is a last resort. Particularly within the context of the publicly held firm, the available evidence suggests to us that the contracting process within the corporation-even in the face of the agency cost shibboleth-is the starting place for answering the question whether firms should be permitted to pay greenmail. ${ }^{19}$

Gordon and Kornhauser reveal their approach to legal scholarship in the conclusion of their comment where they opine that "[t]he policymaker's dilemma is that she cannot wait until the completion of a fully developed model of a controversial transaction or practice before deciding how to respond." 20 This assumption-that the policymaker cannot wait until the market has run its ugly course-separates their approach from ours. In the introduction to A Theoretical Model of Corporate Greenmail, we identified ourselves with a much different school of legal writing when we stated that

an inability to explain certain aspects of exchanges among freely contracting parties does not necessarily mean that the exchanges

16. Gordon \& Kornhauser, supra note 1, at 297.

17. Id. at $320-21$.

18. For further elaboration on the views of regulation held by McChesney and myself, see Macey, Promoting Public-Regarding Legislation Through Statutory Interpretation: An Interest Group Model, 86 Colum. L. REv. 223 (1986); Macey, Special Interest Groups Legislation and the Judicial Function: The Dilemma of Glass-Steagall, 33 EMORY L.J. 1 (1984); McChesney, Government Prohibitions on Volunteer Firefighting in 19th Century America: A Property Rights Perspective, 15 J.L. STUD. 69 (1986).

19. As far as I can tell, Gordon and Kornhauser presuppose that firms operate or should operate under a regime of central planning. Their position seems to be that in the absence of specific rules permitting transactions such as greenmail, such transactions should be illegal until their merits have been established.

20. Gordon \& Kornhauser, supra note 1, at 320-21. 
themselves are socially undesirable. And even if the exchanges harm some firms, those same transactions may benefit others. Some firms may wish to restrict use of greenmail for themselves; others may not. Regulatory or judicial changes that would restrict greenmail across the board deprive shareholders in at least some firms of a legitimate means of protecting or advancing their interests in certain situations. ${ }^{21}$

We presume that mutually agreed-upon exchanges are likely to benefit the contracting parties. We expect more "losers" when a transaction is in its infancy than when those engaging in the transaction are more experienced. ${ }^{22}$ Gordon and Kornhauser apparently do not assign value to this additional experience; they presume that it is imperative to regulate at once. By contrast, we find the argument for experience so compelling that even if the evidence did not show that greenmail payments benefit shareholders in the aggregate, we would favor waiting before regulating.

Markets seldom operate on the basis of perfect information, particularly when forced to evaluate transactions like greenmail with which there is relatively little prior experience. Regulating greenmail payments out of existence before they are fully understood would prevent market forces from developing mechanisms for distinguishing greenmail payments that are beneficial from those that are not. ${ }^{23}$

If the market is allowed to operate in this arena, over time shareholders of different firms may develop a variety of tests to determine when managers may pay greenmail. For example, shareholders might decide to permit greenmail only when an outsider who acquires a "toehold" threatens to disrupt friendly merger negotiations already in progress. Similarly, shareholders might decide to permit greenmail only in situations in which a bidder other than the "greenmailer" expresses a strong interest in the target firm. Still other shareholders may decide that greenmail can be paid only when investment bankers or other outside experts conclude that higher bidders are likely to emerge after such a payment is made. Some or all of these shareholders might prohibit managers who have paid green-

21. Macey \& McChesncy, supra note 2, at 16 (footnotes omitted).

22. See I. KiRzNER, CoMpetTtion AND ENTREPRENEURSHIP 10 (1973) ("The market process, then, is set in motion by the results of the initial market-ignorance of the participants. The process itself consists of the systematic plan changes generated by the flow of market information released by market participation-that is, by testing the plans in the market.").

23. We submit that this difference in approach to issues of corporate governance led Gordon and Kornhauser to charge us, along with Professors Bradley and Rosenzweig, with making "key hidden assumptions" in our theoretical models. Gordon \& Kornhauser, supra note 1, at 297 . We must confess to a bit of confusion about the basic point that Gordon and Kornhauser are trying to establish. Immediately after condemning our work for concealing important assumptions, Gordon and Kornhauser applaud the "extremely useful functions" that our model has served in "clarifying assumptions and forcing deeper analysis" of the issues we discuss. Id. We find it difficult to imagine how we managed to clarify assumptions by concealing them. 
mail from engaging in defensive tactics for a certain period after the payment is made in order to maximize the probability that another bidder will emerge.

The above discussion has suggested various in-house rules that firms could adopt to minimize harmful greenmail payments and maximize beneficial ones. Gordon and Kornhauser do not even entertain the possibility that regulators might be able to sift out beneficial greenmail payments from harmful ones. In this respect, the standards Gordon and Kornhauser set for policymakers are notably less rigorous than the standards by which we judge the efficacy of market forces. For a Gordon and Kornhauser policymaker to be successful, she must simply develop a crude rule which either permits or prohibits greenmail, depending on whether the gross number of winners outnumbers the gross number of losers. For an intrafirm contract to be successful, it must accomplish a good deal more.

Even when given wide latitude in corporate affairs, managers are constrained by market forces to act in the interests of shareholders. ${ }^{24}$ The wisest course is to study the costs and benefits of new economic phenomena carefully before deciding whether or how to regulate them.

\section{The Role of Chance and Self-Interested Management}

We also disagree profoundly with Gordon and Kornhauser about the role of luck in providing wealth to shareholders. Gordon and Kornhauser complain that shareholders often benefit from greenmail payments "strictly by chance." 28 They suggest that "[i]n a certain number of cases ... self-interested management may simply be wrong in its unfavorable assessment of the likelihood of a third party bid."23 Specifically, they envision a scenario in which incumbent management is faced with ouster in a hostile takeover attempt by a first bidder who has acquired a substantial minority block of shares. The managers, desperate to hold onto their jobs, pay greenmail to this bidder in the mistaken belief that no other bidder will emerge. Subsequently, much to the chagrin of incumbent management, another bidder does make an offer at a substantial premium. Shareholders benefit only because target management happened to make a mistake in its assessment of whether a third bidder would emerge.

Gordon and Kornhauser find this situation deplorable. But as we pointed out in our article, it is doubtful that shareholders would agree. ${ }^{27}$ Investors are unlikely to be particularly concerned with target manage-

24. The evidence is superbly catalogued in Easterbrook, Managers' Discretion and Investors' Welfare: Theories and Evidence, 9 DEL. J. CoRP. L. 540 (1984).

25. Gordon \& Kornhauser, supra note 1, at 320.

26. Id.

27. Macey \& McChesney, supra note 2, at 42. 


\section{Takeovers and Legal Scholarship}

ment's motivations for paying greenmail as long as the payments result in gains for the investors. Furthermore, unlike Gordon and Kornhauser, we believe that chance and guesswork are standard features of a market process, especially at an early stage of evolution. Far from deplorable, chance is vital to the development of a competitive economic system. ${ }^{28}$ The premature regulation advocated by Gordon and Kornhauser threatens to stifle innovation and retard economic growth. ${ }^{28}$

Gordon and Kornhauser also charge us with "mak[ing] key hidden assumptions." "so Specifically, they say that we assume that management must have more favorable and more accurate beliefs than the acquiror about the prospects of a third party bid if greenmail payments are to benefit shareholders. ${ }^{31}$ In fact, as pointed out above, we assume the opposite. We actually share Gordon and Kornhauser's assumption that greenmail is often paid by target firm managers who seek to rid themselves of a worrisome suitor and doubt that another bidder will emerge. If this assumption is true, the uncontrovertible fact is that incumbent management often is wrong in this estimation. Higher bidders often appear after management pays greenmail. $^{32}$ Yet in our model, greenmail can benefit shareholders when the beliefs of faithless managers are less favorable and less accurate, and when the beliefs of faithful managers are more favorable as well as more accurate, than those of the acquiror.

28. See Alchian, Uncertainty, Evolution and Economic Theory, 58 J. Pol. Econ. 211, 214-17 (1950).

29. See I. Kirzner, Discovery and the Capitalist Process 125 (1985).

30. Gordon \& Kornhauser, supra note 1, at 297; see also supra note 23.

31. Id. at 315-16. Gordon and Kornhauser erroneously claim that our model assumes that the bidder makes a two-tier, front-loaded tender offer. Id. at 300. As is clear from our theory, and as we took pains to point out in our article, our model does not require that a bidder make a two-tiered offer:

Even without two-tier bids, greenmail is still of value to target shareholders whenever additional time following an initial offer facilitates the development of an auction for their shares. For example, in an all-or-nothing bid the offeror generally conditions her offer on receiving a certain percentage of the outstanding shares by a certain date. This decreases the likelihood of subsequent bidders trumping the initial offer. Under such circumstances, greenmail may be a useful device for "buying time" to see if better offers develop.

Macey \& McChesney, supra note 2, at 20 n. 31 .

Gordon and Kornhauser also erroneously claim that our model assumes no financial intermediaries. In fact, we neither implicitly nor explicitly make this assumption, as it is not relevant to our theory.

32. See supre text accompanying notes 26-27; see also Macey \& McChesney, supra note 2, at 41 (giving theoretical reasons why greenmail is likely to encourage subsequent bidders); MikKEISON \& RUback, TARgeted Repurchases and Common Stock Returns 3 (Massachusetts Institute of Technology Working Paper No. 1707-86, June, 1986) (within three years following greenmail, about $30 \%$ of repurchasing firms are taken over; by contrast, frequency of control change for firms that do not pay greenmail is only about $10 \%$ ). 


\section{The Role of Empirical Evidence}

Gordon and Kornhauser's genre of legal writing places a heavy burden of persuasion on those who do not favor regulation. From their perspective, if opponents of regulation can point only to empirical evidence coupled with some economic theories about how greenmail benefits shareholders by facilitating an auction market for their shares, nothing should stop the regulators from wading into the morass to restore order. In their view, "[i]f chance elements predominate, then no legal rule is likely to identify ex ante desirable greenmail payments. We are tempted at this point to favor a rule proscribing greenmail entirely." ${ }^{33}$ Here we find the gulf between Gordon and Kornhauser and ourselves at its widest. Their presumption in favor of regulation permits them to ignore scientific evidence that we consider highly relevant. From the outset we considered two empirical studies, one by Mikkelson and Ruback ${ }^{34}$ and the other by Holderness and Sheehan, ${ }^{35}$ central to our inquiry. These were the only unflawed studies of the entire greenmail sequence, ${ }^{38}$ both found statistically significant gains to shareholders from such payments. For us, any theory of greenmail must be consistent with this data to be acceptable at the threshold.

By contrast, Gordon and Kornhauser ignore the data except where they appear to misunderstand it. ${ }^{87}$ For them, two facts trump the empirical evidence that greenmail benefits shareholders. The first is that greenmail harms at least some shareholders. The second is that the motives of target managers who pay greenmail seem to be nefarious.

These facts are less important to us than to Gordon and Kornhauser for several reasons. First, as we explain above, we believe that over time market forces are likely to generate better solutions to problematic greenmail payments than the forces of regulation. Second, our reliance on market solutions leads us to expect economic actors, including managers, to act self-interestedly. Thus we are unconcerned that greenmail is often paid for selfish reasons. Indeed, much of modern financial economics is devoted to explaining how markets transform managerial self-interestedness into firm profits. The successful business enterprise is the one that fashions rules of internal corporate governance that align shareholder interests

\footnotetext{
33. Gordon \& Kornhauser, supra note 1, at 320.

34. See Mikkelson \& Ruback, supra note 11 , at 539-40.

35. See Holderness \& Sheehan, supra note 11, at 571-72.

36. Only one study of the entire greenmail sequence concludes that greenmail harms shareholders. The study is discussed in detail in Macey \& McChesney, supra note 2, at 45-47. For a discussion of the methodological shortcomings of the other studies, see $i d$. at $43-44$ (criticizing time frame), 45-48 (criticizing attribution to greemail of losses due to interim exogenous events).

37. Gordon and Kornhauser claim that "[ $t$ ]he evidence shows that greenmail leads, in the aggregate, to shareholder welfare losses." Gordon \& Kornhauser, supra note 1, at 320.
} 
with management interests. McChesney and I were attempting to elucidate this principle. Gordon and Kornhauser believe that regulation must be used to force managers to act in the shareholders' interests. This approach creates a scholarly agenda whose quest for answers is far more urgent than ours.

\section{GoNCLUSION}

We concluded our article on what we thought to be a rather humble note. We stated that "[w]e have not proven that greenmail is always 'good,' simply that it need not be 'bad." "ss8 Our view has not changed. We believe that regulatory proposals to ban or curtail greenmail are contrary to the best interests of shareholders. In our article, we condemned recent developments in the judicial application of the business judgment rule in contests for corporate control. ${ }^{3 \theta}$ Judges now seem to scrutinize the motives of managers who engage in defensive tactics more closely than in the past. In our view, despite its shortcomings, the business judgment rule as traditionally applied provides the best guide for judges to evaluate the payment of greenmail. ${ }^{40}$ In a nutshell, our theory "counsels against hasty revision of the law."41

I wish to emphasize this last point in closing. The difference between Gordon and Kornhauser's approach and ours is only partially attributable to the fact that Gordon and Kornhauser have a general bias in favor of regulation, while we have a bias against it. We reject the very existence of the immediate "policymaker's dilemma" that drives their approach to problems of corporate governance. Postponing regulation of new phenomena such as greenmail until analysts have had the opportunity to gather and examine the relevant data is imperative. In addition, contracting parties should have an opportunity to craft private solutions to phenomena that initially appear negative.

Regulators would be more successful if they abandoned the notion that there is a policymaker's dilemma that forces them to regulate before the "completion of a fully developed model of a controversial transaction or practice." 42 One of the reasons that this is an exciting time to apply law

\footnotetext{
38. Macey \& McChesney, supra note 2, at 60 .

39. Id. at 55-60.

40. The most obvious shortcoming of the traditional business judgment rule is its use of managerial motivation to evaluate the legality of greenmail. Specifically, under the traditional formulation of the rule, judges prohibit greenmail if impermissible motives are the sole or primary reason for the payment. Cheff v. Mathes, 41 Del. Ch. 494, 504, 199 A.2d 548, 554 (1964). In practice, however, this test does not serve as a constraint on managers' ability to pay greenmail. Macey \& McChesney, supra note 2 , at 60 .

41. Macey \& McChesney, supra note 2, at 61.

42. Gordon \& Kornhauser, supra note 1, at 321.
} 
and economics to the study of corporate law is that many common and well-established patterns of corporate behavior are imperfectly understood. Basic topics, such as dividend policy, ${ }^{43}$ share repurchases ${ }^{44}$ and optimal capital structure, ${ }^{45}$ are only now being explained adequately in the literature. Gordon and Kornhauser suggest that the explanations are obvious and intuitive, and hence that regulators can easily find answers to questions which long have befuddled shareholders and market participants. On closer inspection, however, the world is substantially more complex and uncertain than Gordon and Kornhauser presume. Their quest for an immediate solution to the policymaker's dilemma is at best quixotic.

43. Easterbrook, Two Agency-Cost Explanations of Dividends, 74 AM. EcoN. REv. 650 (1984).

44. Dann, Common Stock Repurchases, 9 J. Fin. Econ. 113 (1981); Masulis, Stock Repurchases by Tender Offer: An Analysis of the Causes of Common Stock Price Changes, 35 J. Fin. 305 (1980).

45. Jensen \& Meckling, Theory of the Firm: Managerial Behavior, Agency Costs and Ownership Structure, 3 J. Fin. EcoN. 305 (1976). 